garded as beneficial in that it is composed of substances of nutritional value to plants, whereas other materials are undoubtedly toxic. The arrival of such airborne matter in aneco system represents an input of nutrient or pollutant and its presence raises several questions of ecological interest. Is the nutrient or toxin input of significant importance in relation to the quantity and rate of movement of that substance in the system already? Is the vegetation which acts as a filter able to absorb the material through the leaves? Is the material washed from the canopy to the soil surface and, if so, is it taken up by plant roots? Of what importance is the material (particularly if it is a pollutant) to consumer organisms especially at the higher levels of food chains?

Goodman and Roberts (Nature, 231, 287 ; 1971) found that considerable quantities of toxic metals can arrive at a vegetation surface as dust. Little ( $E n$ viron. Pollut., 5, 173; 1973) has now raised further questions regarding the behaviour of metal contaminants within ecosystems. He attempted to ascertain whether zinc, lead and cadmium are present chicfly on the surfaces of leaves and can be removed by washing, or whether they are absorbed into leaf tissue. Ho also examined three different tree species in the Bristol area-Ulmus glabra (elm) Qusrcus robur (oak) and Salix alba (willow) - to find out whether they respond differently with respect to the three metals.

Little's report provides some useful information on the behaviour of toxins on leaf surfaces. Washing elm leaves in distilled water removed $67 \%$ of their total zinc burden, $87 \%$ of their lead and $62 \%$ of their cadmium. It seems therefore that the bulk of these metals is present as a deposit on the leaf surfaces and can be carried to the soil by rainwashing. Most of the remainder could only be removed by washing with dilute nitric acid, which implies that this fraction is bound more securely to the leaf surface, possibly by exchange phenomena. Boiling in deionised water for $1 \frac{1}{2}$ $h$ removed the portions of the metals present in the cuticle and within cells; they comprised $7 \%$ of the total zinc, $2 \%$ lead and $4 \%$ of the cadmium in the elm leaves. This tendency for a greater degree of incorporation of zinc and cadmium into the leaf structure reflects the higher solubilities of these metals. The dust input of all these metals must therefore be regarded as high when compared with quantities already present in the vegetation.

Other trees behaved rather differently with respect to the three metals; for example, hawthorn and willow retained larger proportions of zinc and lead after washing than did oak, which may be explained by the thicker, waxy cuticle of oak. Skarr et al. (Nature, 241, 215; 1973) found that some bryophytes (which lack a waxy cuticle) absorb lead and store it in their nuclear membranes. Unfortunately, nothing is known of the uptake of these metals from the soil so that it is impossible to determine the relative importance of foliar absorption. Most of the matter washed from leaf surfaces accumulates in the superficial soil layers, as a result of which shallow rooting herbaceous species may be affected by soil toxicity more than deeper rooting trees.

A further study of dust accumulation, this time in a wetland ecosystem, is described by McLay (Environ. Pollut., 5, $173 ; 1973)$. In an area remote from industrial pollution in California, he examined a small alkaline lake where emergent Scirpus californicus grew around the edge and where Lemna perpusilla was abundant on the surface. Growth of Lemna was found to be significantly greater in the laboratory if washings from Scirpus stems were added to the lake water in which they were grown. McLay fails to demonstrate, however, that the stimulation is a result of additional nutrients from dust. It could quite easily be explained in terms of leaf exudates from Scirpus, either of an inorganic nature or as organic, growth promoting substances.

\section{No smoke without fire}

AN unusual line of research but one that may have environmental significance is the ecology of smoke particulates and charcoal residues from forest and grassland fires. E. V. and B. B. Komarek, who work at the Tall Timbers Research Station, 'Tallahasece, and T. C. Carlysle of the Gainsville Laboratory of the US Department of Agriculture, belicve that airbourne particles from such fires act as environmental cleansing agents. They have found from electron micrography that the plant material which remains after burning has a varied porous structure and they suggest that the particulatcs could act as natural filters.

As a contribution to further studies of the part played by this material in

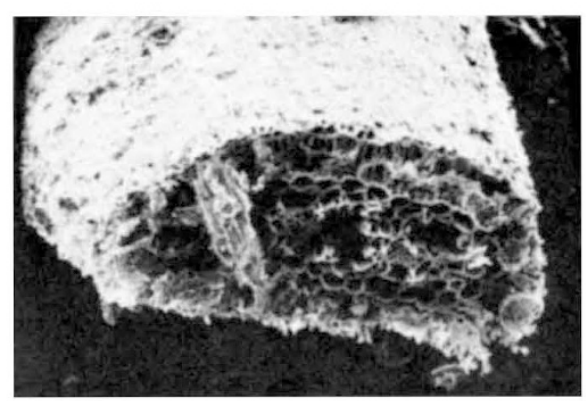

the atmospheric ecosystem, Komarek et al. have prepared an atlas of particulates collected from controlled fires (Misc. Publ. Tall Timbers Research Station, No. 3; 1973). Although the airbourne material and the residues that remain on the ground vary from carbonized matcrial to minerals, white ash, tars and gases, some of the original plant genera can be identified. Species of pine and hardwood trees, grasses and cultivated plants, for example, are represented in the atlas of 136 microphotographs. The figure here shows a cross section of a charred needle of spruce pine (Pinus glabra).

\section{Breaking down \\ bacterial messengers}

\section{from our}

Molecular Genetics Correspondent

Although in most areas of nucleic acid synthesis studies of bacteria have lead the way and research with eukaryotic systems is only now following, the processing of RNA is an exception; for the maturation of ribosomal RNA by cleavage from a large precursor is wcll established in eukaryotes and it is evident also that messenger RNA is initially transcribed in the nucleus in a form much larger than its eventual cytoplasmic size. Two studies reported in the first part of the December Proceedings of the National Academy of Sciences now provide a welcome balance by throwing some light on an enzymatic activity which may be involved in processing RNAs in bacteria.

Using the DNA of phage T7 as a template, Dunn and Studier and others also have shown previously that the messenger RNAs synthesised in vitro are derived by transcription from the beginning of the DNA to a point about $20 \%$ along it, whereas the mRNA found in vivo consists of five smaller species which seem to be derived by cleavage of a precursor corresponding to the in vitro messenger. The enzymatic activity which breaks the precursor down seemed to be very similar to ribonuclease III, one of the known ribonucleases of Escherichia coli. Taking advantage of a mutant strain of $E$. coli deficient in this enzyme, Dunn and Studier now report (ibid., 70, 3296 ; 1973) that this enzyme is implicated in both T7 mRNA cleavage and in rRNA cleavage.

In spite of the absence of a paragraph apparently omitted from the beginning of the "Results" section (this issue of the Proceedings appears with an apology from the editors for its delayed publication and lack of consistency in conventions followed in different papers), it seems that Dunn and Studier have examined the T7 RNAs produced in 